\title{
An Empirical Study About the Effects of 'Business Tax Reformed to VAT' on Firms' Bargaining Power: Based on DID Model
}

\author{
Wang Yanling \\ Shu-UTS Business School, Shanghai University, P.R.China \\ Wang Jiaxi \\ Shanghai University of Finance and Economics, P.R.China
}

Doi:10.19044/esj.2019.v15n7p225 ～URL:http://dx.doi.org/10.19044/esj.2019.v15n7p225

\begin{abstract}
This study empirically examines whether the Business Tax reformed to value added tax (VAT) policy has an impact on the bargaining power of reformed industry firms based on Difference-in-Difference (DID) Model by using the A-share companies listed in both Shanghai Stock Exchange and Shenzhen Stock Exchange from 2010-2015. The bargaining power of firms is divided into two parts: the bargaining power of firms when negotiating with their suppliers and the bargaining power of firms when negotiating with their distributors. We find that the policy does have an impact on the bargaining power of reformed industry firms, specifically, the impact of the policy is to reduce firms' bargaining power when negotiating with suppliers and improve their bargaining power when negotiating with dealers.
\end{abstract}

Keywords: Business Tax reformed to VAT, bargaining power, DID model

\section{Introduction}

'Business Tax reformed to VAT' policy was firstly put into practice in ' $1+6$ ' industries ( 1 means Transportation industry, 6 means Modern Services industry) in Shanghai on January 1, 2012. After that, the reformed area and industries experience a gradual expansion in China from May 1, 2016. The main purpose of the government to implement the policy is to reduce the tax burden of firms, promote economic development and mobilize the enthusiasm of all parties. However, the actual effects of the policy in implementation process are unsure and very complex. Since the implementation of the policy, multifaceted studies have been done to study the actual impacts of it.

Early research on this policy mainly focus on the aspects of firm performance, change of tax burden, division of labor, investment in innovative 
intangible assets, etc. Few studies have examined the influences of the policy on bargaining power of the firm. Previous studies in this area mainly are theoretical analysis and qualitative research. $\mathrm{Hu}$ (2013) finds that the upstream firms' bargaining power could be improved because firms are allowed to deduct input tax deduction after the implementation of the policy, however he uses a qualitative theoretical framework to study this problem. Tong (2015) examines the policy's impact on turnover tax burden basing on different bargaining power. However, bargaining power is not the main point of these literature. In this study, we intend to explore the effect of 'Business Tax reformed to VAT' policy's on firms' bargaining power. During firms' operation, bargaining power is a very important factor. For example, the costs of raw materials are strongly influenced by firms' bargaining power when negotiating with the suppliers. Moreover, the firms' bargaining power when negotiating with the dealers may influence the price of the product, the sales revenue and ultimately the corporation's performance.

Based on the data of Chinese listed companies from 2010 to 2015, this study uses DID model to examine the policy's impact on bargaining power and the possible mechanism of the impact.

The remainder of the paper is organized as follows. Section 2 develops our theoretical framework and presents the hypotheses. Section 3 discusses the sample selection and research design. Descriptive statistics and multivariate analysis are presented in section 4 . Section 5 presents the conclusions.

\section{Theoretical Analysis and Research Hypothesis}

Hu (2013) suggest that the 'Business Tax reformed to VAT' policy might have a certain impact on the bargaining power of firms. After the reform, firms are allowed to carry out input VAT deduction. Therefore, the upstream manufacturers become the invoice issuer and the downstream manufacturers will ask invoice from them in order to deduct input VAT. In the bargaining game, this relationship will make the upstream manufacturers occupy a favorable position and enhance their bargaining power to a certain extent. Relatively, the downstream manufacturers' bargaining power will be weakened.

As shown in Figure 1, the bargaining power of firms can be divided into two parts: dealer bargaining power and supplier bargaining power. For a specific firm involved in the reform, relative to its suppliers, the role of the firm is the dealer and the bargaining power of it when negotiating with suppliers is called the reformed firm's dealer bargaining power. Relative to the dealer, the role of the firm is the supplier. When negotiating with dealers, the bargaining power of the reformed firm is called supplier bargaining power. In the bargaining game with suppliers, the reformed firms are in the 
downstream and they ask for invoice. The power of the reformed firms to bargain with its suppliers will be weakened, that is, the firms' dealer bargaining power will be weakened. In the bargaining game with dealers, the reformed firms are in the upstream and they are the invoice issuer. Since they stay in a favorable position, the power of the reformed firms to bargain with its dealers will be improved, that is, the firms' supplier bargaining power will be improved.

Therefore, as a supplier, after the implementation of the policy, the firms involved in the reform will have stronger power to bargain with its dealers, that means, their supplier bargaining power will be improved. As a dealer, after the implementation of the policy, the power of the firm to bargain with its suppliers will be weakened, that is, their dealer bargaining power will be weakened. Therefore, we state our hypotheses as follows:

H1: Other things unchanged, compared with the control group of nonreformed firms, 'Business Tax reformed to VAT' policy will weaken the dealer bargaining power of experimental group of reformed firms, that is, the experimental group's power to bargain with their suppliers will be weakened.

H2: Other things unchanged, compared with the control group of nonreformed firms, 'Business Tax reformed to $V A T$ ' policy will improve the supplier bargaining power of experimental group of reformed firms, that is, the experimental group's power to bargain with their dealers will be improved.

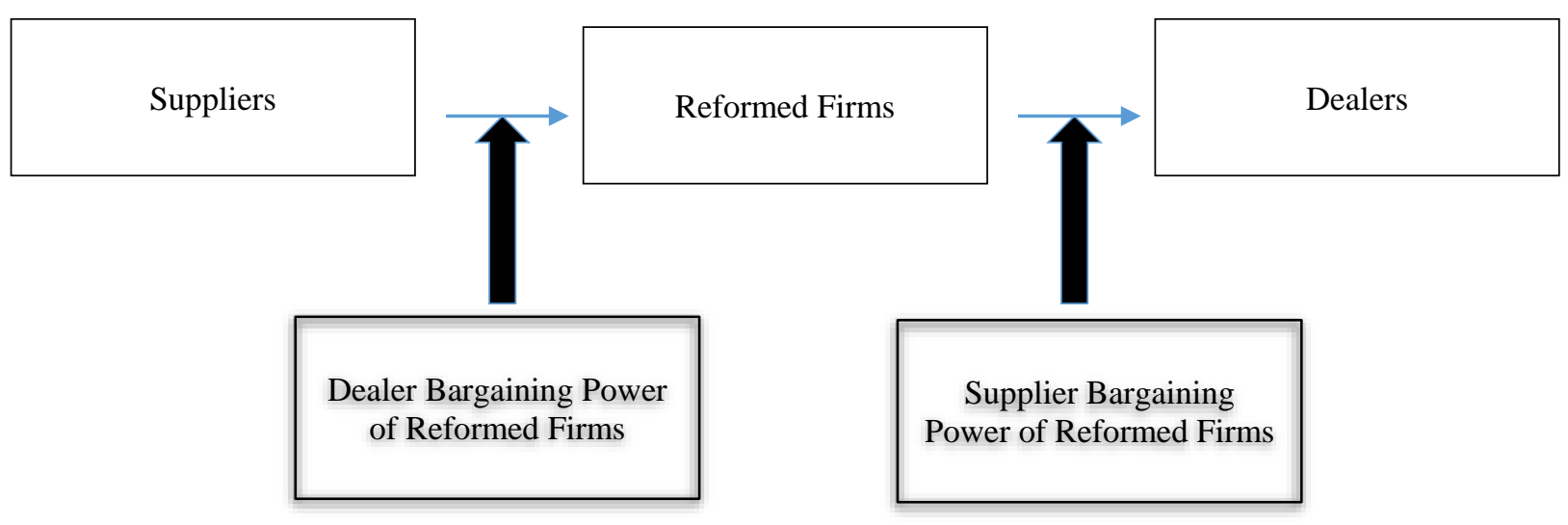

Figure 1. Bargaining Power of the Firm 


\section{Sample Selection and Research Design}

\subsection{Sample Selection and Data Source}

Our sample consists of all Chinese A-share listed companies. Our sample period is 2010-2015. The Sample selection procedure is outlined as follows: we first delete observations with insufficient data to compute firmlevel variables in any year. Then we exclude $S T$ and $S T^{*}$ listed companies. Lastly, we trim extreme observations at the $1^{\text {st }}$ and $99^{\text {th }}$ percentiles based on the bargaining power.

We then divide our sample into two groups, the supplier data group and the dealer data group. 275 listed companies, a total of 1650 observations are included in the supplier data group. 505 listed companies, a total of 3030 observations are included in the dealer data group. In each group the listed companies are further divided into experimental group and control group. The listed companies in the experimental group pay business tax before the reform while VAT after the reform. The listed companies in the control group pay VAT all the time. All the data are collected from the China Securities Markets and Accounting Research (CSMAR) database.

\subsection{Variable Selection and DID Model}

As mentioned earlier, the bargaining power of firms can be divided into dealer bargaining power and supplier bargaining power. When the firm bargain with its dealers, it acts as a supplier. Therefore, the firm's power to bargain with its dealers is reflected in its supplier bargaining power. On the contrary, when bargaining with suppliers, the firm becomes the dealer. Therefore, the firm's power to bargain with its suppliers is reflected in its dealer bargaining power. To construct our empirical proxy for the bargaining power of suppliers and distributors, we estimate the concentration of suppliers and distributors as the dealer bargaining power and supplier bargaining power. Previous studies show that the most commonly used variables to measure the concentration of suppliers and distributors are the top five distributors' and suppliers' share of business. The larger the share of the top five suppliers, the higher the concentration of suppliers. Thus, the higher the degree of dependence of the firm on the suppliers, the weaker the power of the firm to bargain with its suppliers, that is, the weaker the dealer bargaining power of the firms. On the other hand, the lower the share of the top five dealers, the lower the concentration of dealers. Thus, the lower the degree of dependence of the firm on the dealer, the stronger the power of the firm to bargain with its dealers (Tang, 2009), that means, the supplier bargaining power of firms is stronger. In short, the business share change of the top five dealers and suppliers of listed companies will be used to measure the change in supplier and dealer bargaining power. 
When the power of the firm to bargain with its suppliers is weakened, the degree of their dependence on suppliers will be improved. Reflected in the proxy variables, the share of top five suppliers will increase. At the same time, the degree of dependence on dealers will decrease if the power of the firm to bargain with dealers is enhanced. Reflected in the proxy variables, the share of top five dealers will decrease. Usually, the DID model is used to evaluate the impact of the change of the policy (Ye, 2013). This study applies the DID model to examine the effect of 'Business Tax reformed to VAT' policy's on firms' bargaining power. We set the reformed listed companies as the treat group, and the non-reformed listed companies as the control group. The model is constructed as follows:

$$
\begin{gathered}
\text { Power }_{\text {ilt }}=\alpha \text { Policy }_{l t}+\text { BTreat }_{i}+\gamma \text { Policy }_{l t} * \text { Treat }_{i}+\theta_{t}+\delta_{i} \\
+ \text { Timetrend }_{i}+\varepsilon_{\text {ilt }}
\end{gathered}
$$

Power $_{\text {ilt }}$ means firm $i$ 's top five suppliers or dealers share in the location of province $l$ for year $t$. We set the indicator variable Policy $y_{l t}$ to 1 if province $l$ is included in the reformed area for year $\mathrm{t}$, and 0 otherwise. Treat ${ }_{i}$ equals 1 if firm $i$ is a reformed firm, and 0 otherwise. The difference-in-differences effect is captured by Policy $_{i t} *$ Treat $_{i}$. We use $\theta_{t}$ to control the fixed effect of year and $\delta_{i}$ to control for the firm fixed effect. The provinces are allowed to have different linear trends over time and the changes are showed by the variable Timetrend $_{i}$. The meaning of each variable is summarized in Table 1, and Table 2 shows the change in reformed areas and industries over time.

Table 1. Variable Definitions

\begin{tabular}{|c|l|}
\hline Variables & \multicolumn{1}{c|}{ Meanings } \\
\hline Power $_{\text {ilt }}$ & $\begin{array}{l}\text { The share of top five suppliers or dealers of firm i in province 1 } \\
\text { in year t }\end{array}$ \\
\hline Policy $_{l t}$ & $\begin{array}{l}\text { Whether province 1 is included in the reformed area in year t or } \\
\text { not }\end{array}$ \\
\hline Treat $_{i}$ & Whether firm i is a reformed firm or not \\
\hline$\theta_{t}$ & The year fixed effect \\
\hline$\delta_{i}$ & The firm fixed effect \\
\hline Timetrend $_{i}$ & $\begin{array}{l}\text { The product of year dummy variables and province dummy } \\
\text { variables }\end{array}$ \\
\hline
\end{tabular}


Table 2. The Change in Reformed Areas and Industries

\begin{tabular}{|c|c|c|}
\hline The Starting Time & Reformed Industry & Reformed Areas \\
\hline January 1,2012 & ' $1+6$ ' Industry & Shanghai \\
\hline September 1, 2012 & ‘'1+6’ Industry & Beijing \\
\hline October 1,2012 & ' $1+6$ ' Industry & $\begin{array}{l}\text { Anhui Province, Jiangsu } \\
\text { Province } \\
\end{array}$ \\
\hline November 1,2012 & '1+6’ Industry & $\begin{array}{c}\text { Fujian Province, } \\
\text { Guangdong Province }\end{array}$ \\
\hline December 1, 2012 & ' $1+6$ ' Industry & $\begin{array}{l}\text { Hubei Province, } \\
\text { Zhejiang Province, } \\
\text { Tianjin Province }\end{array}$ \\
\hline August 1, 2013 & ' $1+6$ ' Industry & The Whole Country \\
\hline August 1, 2013 & $\begin{array}{c}\text { Radio and Television Service } \\
\text { Industry }\end{array}$ & The Whole Country \\
\hline January 1,2014 & $\begin{array}{c}\text { Rail Transport Industry, Postal } \\
\text { Industry }\end{array}$ & The Whole Country \\
\hline June 1, 2014 & Telecommunications Industry & The Whole Country \\
\hline
\end{tabular}

Note: '1+6' Industry means 1 Transportation industry plus 6 Modern Services industry

According to Tong (2015) and Tang (2009), we include firm size (natural log of total assets), concentration ratio (Hirschman-Herfindahl Index), the nature of firm's ownership, accounts receivable ratio and accounts payable ratio as our control variables.

In the above model, we focus on the coefficient of Policy $i t *$ Treat $_{i}$. Only when Treat $i$ and Policy $y_{i t}$ both equal 1, the variable Policy $i t *$ Treat $_{i}$ will have an effect on the Power. When Policy it $_{*}$ Treat $_{i}$ equals 1 , it means that the firm is a reformed firm in a reformed area and in the reformed year. According to hypothesis 1, compared to the non-reformed listed companies, the coefficient of Policy $_{i t} *$ Treat $_{i}$ is expected to be significantly positive if the power of reformed firms to bargain with suppliers is indeed weakened. According to hypothesis 2, compared to the non-reformed listed companies, the coefficient of Policy $_{i t} *$ Treat $_{i}$ is expected to be significantly negative if the power of reformed firms to bargain with dealers is improved.

\section{Empirical Results and Analysis}

\subsection{Descriptive statistics}

Table 3 show the descriptive statistics of our main variables. Panel A shows the descriptive statistics for the supplier data group while panel B shows the descriptive statistics for the dealer data group. The number of observations for the dealers' group is greater than the number of observations for the supplier's data group ( 3,030 versus 1,650). The mean (median) value of Power were 35.717 (31.90) for the supplier data group and 30.845 (45.515) for the dealer's data group. The mean value of Treat is higher for the supplier data 
group than for the dealer's data group. There is no big difference of the mean value of Policy between these two groups.

Table 3. Descriptive Statistics of Main Variables

\begin{tabular}{|c|c|c|c|c|c|}
\hline \multicolumn{7}{|c|}{ Panel A: The Suppliers Data Group (n=1,650) } \\
\hline Variable & Mean & Median & $\begin{array}{c}\text { Standard. } \\
\text { Deviation. }\end{array}$ & Min & Max \\
\hline Power & 35.717 & 31.90 & 19.139 & 0.69 & 100 \\
\hline Treat & 0.425 & 0 & 0.495 & 0 & 1 \\
\hline Policy & 0.513 & 1 & 0.499 & 0 & 1 \\
\hline \multicolumn{7}{|c|}{ Panel B: The Dealers Data Group (n=3,030) } \\
\hline Variable & Mean & Median & $\begin{array}{c}\text { Standard. } \\
\text { Deviation. }\end{array}$ & Min & Max \\
\hline Power & 30.845 & 45.515 & 20.873 & 1.06 & 100 \\
\hline Treat & 0.143 & 0 & 0.35 & 0 & 1 \\
\hline Policy & 0.56 & 1 & 0.489 & 0 & 1 \\
\hline
\end{tabular}

\subsection{Empirical Results}

\subsubsection{Analysis on the Influence of 'Business Tax Reformed to VAT' on Firms' Dealer Bargaining Power}

Table 4. Analysis of the Policy Effects on Dealer Bargaining Power of reformed firm

\begin{tabular}{|c|c|c|c|c|c|}
\hline & $(1)$ & (2) & (3) & (4) & (5) \\
\hline & OLS & OLS & OLS & $\mathrm{FE}$ & $\mathrm{FE}$ \\
\hline & Power jxs & Power jxs & Power jxs & Power jxs & Power jxs \\
\hline Treat & $\begin{array}{c}-7.142 * * * \\
(0.001)\end{array}$ & $\begin{array}{c}-6.914 * * * \\
(0.001)\end{array}$ & $\begin{array}{c}-6.941 * * * \\
(0.002)\end{array}$ & & \\
\hline Policy & $\begin{array}{l}-2.023 * * \\
(0.030)\end{array}$ & $\begin{array}{c}-7.378 * * * \\
(0.004)\end{array}$ & $\begin{array}{c}-5.947 * * * \\
(0.001)\end{array}$ & $\begin{array}{c}-5.394 * * * \\
(0.001)\end{array}$ & $\begin{array}{c}-4.663 * * * \\
(0.001)\end{array}$ \\
\hline Treat*Policy & $\begin{array}{c}13.171 * * * \\
(0.000)\end{array}$ & $\begin{array}{c}13.048 * * * \\
(0.000)\end{array}$ & $\begin{array}{c}13.327 * * * \\
(0.000)\end{array}$ & $\begin{array}{c}12.210 * * * \\
(0.000)\end{array}$ & $\begin{array}{c}11.593 * * * \\
(0.000)\end{array}$ \\
\hline $\begin{array}{c}\text { Fixed Effect of } \\
\text { Year }\end{array}$ & & Yes & Yes & Yes & Yes \\
\hline Timetrend & & & Yes & & Yes \\
\hline $\begin{array}{c}\text { Firm' Fixed } \\
\text { Effects }\end{array}$ & & & & Yes & Yes \\
\hline Constant Term & $\begin{array}{c}36.484 * * * \\
(0.000)\end{array}$ & $\begin{array}{c}35.677 * * * \\
(0.000)\end{array}$ & $\begin{array}{c}29.096 * * * \\
(0.000)\end{array}$ & $\begin{array}{c}32.736 * * * \\
(0.000)\end{array}$ & $\begin{array}{c}- \\
1.1 \mathrm{e}+03 * * * \\
(0.000)\end{array}$ \\
\hline \multicolumn{6}{|c|}{ Control variables included but not reported for the sake of brevity } \\
\hline$N$ & 1650 & 1650 & 1650 & 1650 & 1650 \\
\hline Within $\mathrm{R}^{2}$ & 0.036 & 0.041 & 0.094 & 0.117 & 0.161 \\
\hline
\end{tabular}

Note: The values in parentheses are $\mathrm{P}$ values. All results are calculated using the clustering standard error at the provincial level. $* * * * *$ and $*$ represent $1 \%$ 、5\%和 $10 \%$ significance levels. Power.gys means supplier bargaining power of firms. Power,jxs means dealer bargaining power of firms. 
Results of the policy effects on dealers bargaining power of the reformed firm are presented in Table 4. For the sake of comparisons, regressions are reported with and without fixed effect of firm and year. Policy $_{i t} *$ Treat $_{i}$ are significantly positive in the normal OLS and the fixed effect regressions, indicating that the policy does improve the top five suppliers' share of the reformed firm. This suggests that the'Business Tax Reformed to VAT'policy does enhance the top five suppliers' concentration, improve the reformed firms' degree of dependence on its suppliers, reduce the dealers bargaining power of the reformed firm. This supports Hypothesis 1 .

\subsubsection{Analysis on the Influence of 'Business Tax Reformed to VAT' on Firms' Supplier Bargaining Power}

Table 5. Analysis of the Policy Effects on Supplier Bargaining Power of reformed firm

\begin{tabular}{|c|c|c|c|c|c|}
\hline & (1) & (2) & (3) & (4) & $(5)$ \\
\hline & OLS & OLS & OLS & FE & FE \\
\hline & Power_gys & Power_gys & Power_gys & Power_gys & Power_gys \\
\hline Treat & $\begin{array}{c}12.438 * * * \\
(0.000)\end{array}$ & $\begin{array}{c}-12.346^{* * *} \\
(0.000) \\
\end{array}$ & $\begin{array}{c}-11.439 * * * \\
(0.000)\end{array}$ & & \\
\hline Policy & $\begin{array}{l}1.602^{*} \\
(0.067) \\
\end{array}$ & $\begin{array}{c}1.146 \\
(0.642) \\
\end{array}$ & $\begin{array}{c}2.473 * * \\
(0.017) \\
\end{array}$ & $\begin{array}{l}2.274 * * \\
(0.022) \\
\end{array}$ & $\begin{array}{l}1.724^{*} \\
(0.065) \\
\end{array}$ \\
\hline Treat*Policy & $\begin{array}{c}-5.284 * * * \\
(0.002)\end{array}$ & $\begin{array}{c}-5.409 * * * \\
(0.002)\end{array}$ & $\begin{array}{c}-5.416 * * * \\
(0.002)\end{array}$ & $\begin{array}{c}-4.706 * * * \\
(0.001)\end{array}$ & $\begin{array}{c}-3.472 * * * \\
(0.007)\end{array}$ \\
\hline $\begin{array}{c}\text { Fixed Effect of } \\
\text { Year }\end{array}$ & & Yes & Yes & Yes & Yes \\
\hline Timetrend & & & Yes & & Yes \\
\hline $\begin{array}{c}\text { Firm's Fixed } \\
\text { Effect }\end{array}$ & & & & Yes & Yes \\
\hline Constant Term & $\begin{array}{c}43.892 * * * \\
(0.000)\end{array}$ & $\begin{array}{c}43.141 * * * \\
(0.000)\end{array}$ & $\begin{array}{c}33.929 * * * \\
(0.000)\end{array}$ & $\begin{array}{c}39.719 * * * \\
(0.000)\end{array}$ & $\begin{array}{c}619.126 * * * \\
(0.000) \\
\end{array}$ \\
\hline \multicolumn{6}{|c|}{ Control variables included but not reported for the sake of brevity } \\
\hline $\mathrm{N}$ & 3030 & 3030 & 3030 & 3030 & 3030 \\
\hline Within R2 & 0.093 & 0.094 & 0.144 & 0.014 & 0.057 \\
\hline
\end{tabular}

Note: The values in parentheses are $\mathrm{P}$ values. All results are calculated using the

clustering standard error at the provincial level. ***,**and* represent $1 \% 、 5 \%$ 和

$10 \%$ significance levels. Power.gys means supplier bargaining power of firms. Power,jxs means dealer bargaining power of firms.

Results of the policy effects on suppliers bargaining power of the reformed firm are presented in Table 5. For the sake of comparisons, regressions are reported with and without fixed effects of firm and year. Policy $_{i t} *$ Treat $_{i}$ are significantly negative in the normal OLS and the fixed effect regressions, indicating that the policy does reduce the top five dealers' share of the reformed firm. This suggests that the 'Business Tax Reformed to VAT'policy does lower the top five dealers' concentration, weaken the reformed firms' degree of dependence on its dealers, improve the suppliers bargaining power of the reformed firm. This supports Hypothesis 2. 


\subsubsection{Sub-industry Test Results}

Then we examine the impact of the policy on the bargaining power of different industries and firms. Until 2015, there are three major categories of industries that have been reformed: transportation industry, telecommunications industry and modern service industry, respectively. Among the experimental groups that have been reformed, modern service industry includes leasing and business services, cultural sports and entertainment, health and social work service, radio and television services, and scientific research and technical services. We use the sub-industry test to examine whether the policy has significant impacts on the bargaining power of firms in reformed industry, whether there is any difference of the impacts on different industries. Results are shown in Table 6:

Table 6. Empirical Results of Sub-Industry Test

\begin{tabular}{|c|c|c|c|c|c|c|}
\hline & (1) & (2) & (3) & (4) & $(5)$ & (6) \\
\hline & \multicolumn{2}{|c|}{$\begin{array}{l}\text { Telecommunications } \\
\text { Industry }\end{array}$} & \multicolumn{2}{|c|}{$\begin{array}{l}\text { Transportation } \\
\text { Industry }\end{array}$} & \multicolumn{2}{|c|}{$\begin{array}{c}\text { Modern Services } \\
\text { Industry }\end{array}$} \\
\hline & Power_jxs & $\begin{array}{c}\text { Power_g } \\
\text { ys }\end{array}$ & $\begin{array}{c}\text { Power_jx } \\
\text { s }\end{array}$ & $\begin{array}{c}\text { Power_g } \\
\text { ys }\end{array}$ & $\begin{array}{c}\text { Power_jx } \\
\text { s }\end{array}$ & $\begin{array}{c}\text { Power_g } \\
\text { ys }\end{array}$ \\
\hline Policy & $\begin{array}{l}-1.679 \\
(0.268) \\
\end{array}$ & $\begin{array}{c}1.101 \\
(0.243) \\
\end{array}$ & $\begin{array}{l}-2.306 \\
(0.146) \\
\end{array}$ & $\begin{array}{c}0.594 \\
(0.490) \\
\end{array}$ & $\begin{array}{c}-3.747 * * \\
(0.011) \\
\end{array}$ & $\begin{array}{c}1.309 \\
(0.165) \\
\end{array}$ \\
\hline $\begin{array}{l}\text { Treat*Poli } \\
\text { cy }\end{array}$ & $\begin{array}{c}11.117 * * * \\
(0.000)\end{array}$ & $\begin{array}{l}-2.772 * \\
(0.064)\end{array}$ & $\begin{array}{c}6.544 * * * \\
(0.006)\end{array}$ & $\begin{array}{l}-3.875^{*} \\
(0.096)\end{array}$ & $\begin{array}{c}13.187 * * \\
* \\
(0.000)\end{array}$ & $\begin{array}{l}-4.164 * \\
(0.062)\end{array}$ \\
\hline $\begin{array}{l}\text { Year Fixed } \\
\text { Effect }\end{array}$ & Yes & Yes & Yes & Yes & Yes & Yes \\
\hline Tinetrend & Yes & Yes & Yes & Yes & Yes & Yes \\
\hline $\begin{array}{l}\text { Firm Fixed } \\
\text { Effect }\end{array}$ & Yes & Yes & Yes & Yes & Yes & Yes \\
\hline $\begin{array}{c}\text { Constant } \\
\text { Term }\end{array}$ & $\begin{array}{c}- \\
914.170 * * * \\
(0.000)\end{array}$ & $\begin{array}{c}349.396 * \\
* * \\
(0.000)\end{array}$ & $\begin{array}{c}731.475 * \\
* * \\
(0.000)\end{array}$ & $\begin{array}{c}1376.133 \\
* * * \\
(0.000)\end{array}$ & $\begin{array}{c}-86.880 \\
(0.673)\end{array}$ & $\begin{array}{c}1467.810 \\
* * * \\
(0.000)\end{array}$ \\
\hline \multicolumn{7}{|c|}{ Control variables are included but not reported for the sake of brevity } \\
\hline $\mathrm{N}$ & 1302 & 2610 & 1056 & 2346 & 1188 & 2454 \\
\hline Within $\mathrm{R}^{2}$ & 0.145 & 0.060 & 0.093 & 0.071 & 0.141 & 0.060 \\
\hline
\end{tabular}

Note: The values in parentheses are $\mathrm{P}$ values. All results are calculated using the clustering standard error at the provincial level. ***,**and* represent $1 \% 、 5 \%$ 和 $10 \%$ significance levels. Power.gys means supplier bargaining power of firms. Power,jxs means dealer bargaining power of firms.

As can be seen, Policy $_{i t} *$ Treat $_{i}$ are significantly positive in all regressions of the supplier's data group and significantly negative in all regressions of the dealer's data group.

The results are consistent with $\mathrm{H} 1$ and $\mathrm{H} 2$.

\subsubsection{Sub-regional Test Results}

In addition, we also examine the impact of the policy on the bargaining power of firms from different regions. In the sub-regional research, we study whether the policy has significant impacts on the bargaining power of firms in 
all reformed areas, whether there is any difference of the impact on firms in the specific reformed area. We divide the area into three regions: The Central, the West and the East according to National Bureau of Statistics of China. Specifically, Shanxi province, Neimenggu province, Jilin province, Heilongjiang province, Anhui province, Jiangxi province, Henan province, Hubei province, and Hunan province are included in the Central region. The West region includes Sichuan province, Chongqing, Guizhou province, Yunnan province, Xizang province, Shanxi province, Gansu province, Ningxia province, Qinghai province and Xinjiang province. The East region includes Beijing, Tianjin, Hebei province, Liaoning province, Shanghai, Jiangsu province, Zhejiang province, Fujian province, Guangdong province, Guangxi province and Hainan province. Results are shown in Table 7:

Table 7. Empirical Results of Sub-Regional Test

\begin{tabular}{|c|c|c|c|c|c|c|}
\hline & (1) & (2) & (3) & (4) & (5) & (6) \\
\hline & \multicolumn{2}{|c|}{ The East Region } & \multicolumn{2}{|c|}{ The Central Region } & \multicolumn{2}{|c|}{ The West Region } \\
\hline & Power_jxs & $\begin{array}{c}\text { Power_g } \\
\text { ys }\end{array}$ & Power_jxs & $\begin{array}{c}\text { Power_g } \\
\text { ys }\end{array}$ & $\begin{array}{c}\text { Power_ } \mathrm{j} \\
\text { xs }\end{array}$ & Power_gys \\
\hline Policy & $\begin{array}{c}-6.063 * * * \\
(0.010)\end{array}$ & $\begin{array}{l}1.294 * \\
(0.078)\end{array}$ & $\begin{array}{l}-2.918 \\
(0.140)\end{array}$ & $\begin{array}{l}-1.956 \\
(0.335)\end{array}$ & $\begin{array}{l}-0.665 \\
(0.856)\end{array}$ & $\begin{array}{c}13.942 * * * \\
(0.000)\end{array}$ \\
\hline $\begin{array}{l}\text { Treat*Poli } \\
\text { cy }\end{array}$ & $\begin{array}{c}12.309 * * * \\
(0.000)\end{array}$ & $\begin{array}{c}-3.125 * * \\
(0.041)\end{array}$ & $\begin{array}{c}9.860 * * \\
(0.012)\end{array}$ & $\begin{array}{c}-6.795 * * \\
(0.040)\end{array}$ & $\begin{array}{l}10.856 \\
(0.104) \\
\end{array}$ & $\begin{array}{r}-2.149 \\
(0.704) \\
\end{array}$ \\
\hline $\begin{array}{c}\text { Year Fixed } \\
\text { Effect }\end{array}$ & Yes & Yes & Yes & Yes & Yes & Yes \\
\hline Timetrend & Yes & Yes & Yes & Yes & Yes & Yes \\
\hline $\begin{array}{c}\text { Firm Fixed } \\
\text { Effect }\end{array}$ & Yes & Yes & Yes & Yes & Yes & Yes \\
\hline Constant & $\begin{array}{c}- \\
3.1 \mathrm{e}+03 * * \\
* \\
(0.003) \\
\end{array}$ & 537.043 & $\begin{array}{c}878.387 * * \\
* \\
\\
(0.000) \\
\end{array}$ & $(0.282)$ & 1193.250 & $\begin{array}{c}4269.887 * \\
* * \\
(0.001) \\
\end{array}$ \\
\hline \multicolumn{7}{|c|}{ Control variables are included but not reported for the sake of brevity } \\
\hline $\mathrm{N}$ & 1236 & 2154 & 246 & 474 & 168 & 402 \\
\hline Within $\mathrm{R}^{2}$ & 0.180 & 0.040 & 0.105 & 0.105 & 0.194 & 0.093 \\
\hline
\end{tabular}

Note: The values in parentheses are $\mathrm{P}$ values. All results are calculated using the clustering standard error at the provincial level. ***,**and* represent $1 \%$ 、5\%和 $10 \%$ significance levels. Power.gys means supplier bargaining power of firms. Power,jxs means dealer bargaining power of firms.

The results are shown in table 7. For the sample from the East region and Central region, Policy $_{i t} *$ Treat $_{i}$ is significantly positive in the suppliers data group and significantly negative in the dealers data group, indicating that 'Business Tax Reformed to VAT' improves the supplier bargaining power of reformed firms in central and eastern regions and weakens the dealers bargaining power of them. However, for the sample from the West region, although Policy $_{i t} *$ Treat $_{i}$ is positive in suppliers data group and negative in 
dealers data group, neither of them is significant. This suggests that the bargaining power of the reformed firms in the western region has not been significantly affected by the 'Business Tax Reformed to VAT' policy. There are several reasons for this: First, it is relatively late for the west region to be included in the reformed scope, so maybe the policy effect has not been fully reflected in such a short period of time. Second, the reformed firms in the western region mainly belong to telecommunications industry. It is also very late for this industry to be included in the reformed industries. Last but not least, the economy of the western region is relatively backward compared to the central and eastern regions, and the relevant policy may be more likely to be hampered during the implementation.

\section{Conclusion and Recommendations}

Based on the data of Chinese A-share listed companies from 2010 to 2015, this study uses the difference-in-differences (DID) model to examine the impact of 'Business Tax Reformed to VAT' policy on firms' bargaining power. We find that the policy does have a significant impact on the bargaining power of the firms in the experimental group. Specifically, the policy weakens the firm's power to bargain with suppliers, that is, the dealers bargaining power of the reformed firm is weakened. In addition, the policy improves the reformed firms' power to bargain with dealers, namely, the reformed firms' supplier bargaining power is improved. The sub-industry regressions are similar. The sub-regional regressions show that the policy has significant impacts on reformed firms in the central and eastern regions while the western region has not been significantly influenced. We believe our findings are potentially informative to regulators, suppliers and dealers.

When the dealer bargaining power of the firm is weakened, the costs of its raw materials will go up. Assume all the other things stay the same, the total product costs of the firm will increase, and the cost of goods sold will boost, so the profit of the firm will decline. This will have a negative effect on the firm's performance. However, at the same time, the supplier bargaining power of the firm is enhanced, so it can raise the product price to boost sales revenue. Firms need to balance these two effects. On one hand, they will take full advantage of the benefits brought by the policy. On the other hand, it is also necessary for them to try to minimize the negative impacts of the policy.

The implementation of 'Business Tax Reformed to VAT' policy does bring benefits to some firms, but it can also have some negative impacts on others. How to maximize total welfare of the whole society is a challenge for the government. In this study, we find that 'Business Tax Reformed to VAT' policy affects reformed firms' bargaining power through input tax deduction. The upstream firms are positively affected by the policy while the downstream 
ones are negatively influenced. This policy may lead to the redistribution of social resources and rights and change the competition environment of the market. Future research, exploring the role of government in establishing a sound value-added tax system corresponding to Chinese laws and regulations, would be useful.

\section{References:}

1. Bashir T., Mansha A., Zulfiqar R. and Riaz R. (2014). Impact on FDI Economy Growth: A Comparison of South Asian States\& Chian. European Scientific Journal, Vol 10, No1. 446-469

2. Cai X. (2012) 'Business Tax Reformed to VAT' reform steadily progress to achieve the stage effect', China Taxation News, pp.1128.

3. Cao H. (2010) Government regulation under different bargaining power of the theme of the game analysis. Shanghai Normal University, Shanghai.

4. Cela G.(2018) The impact assessment of the VAT reduction in Tourism Sector. European Scientific Journal, Vol 14, No25. 243-255

5. Chi R.Y. \& Zhu F. (2012) "Analysis of influencing factors of firm bargaining power: Zhejiang product empirical study", Journal of Zhejiang University of Technology, no.1, pp. 1-5.

6. Duan H.F. (2012) Research on 'Business Tax Reformed to VAT' in China's transportation industry. Zhejiang Institute of Finance and Economics, Hangzhou.

7. Tang Y.J. (2009) "Supplier, dealer bargaining power and company performance", China Industrial Economy, no.10, pp. 67-76.

8. Gong H.F. (2016) "Financial industry, construction industry and 'Business Tax Reformed to VAT' problem research", Gansu Finance, no.1, pp.42-43.

9. Hu Y.J. (2014) "Comprehensive deepening 'Business Tax Reformed to VAT' needs to promote the three breakthrough" Registered Tax Accountants, no.8, pp. 67-68.

10. Hu Y.J. (2013) "Shanghai service industry 'Business Tax Reformed to VAT' reform effect analysis". Science Development, no.1, pp. 5564.

11. Huang J.Z. (2014) "Advantages and disadvantages of 'Business Tax Reformed to VAT' on modern service industry", Modern Economic Information, no.3, pp. 230-238.

12. Li D. (2015) "Business Tax Reformed to VAT' policy effect on tax burden of transportation industry" Journal of Shanghai Institute of Shipping and Transportation Science, no.6, pp. 71-74. 
13. Lin Y.L. (2015) "Exploring the French 'Business Tax Reformed to VAT' impact on China's tax reform", Modern Business, no.6, pp. 8081.

14. Liu R.Z., et al. (2015) 'Business Tax Reformed to VAT' impact on investment, R\&D and employment of firms - based on DID model", China Economic Issues, no.4, pp. 3-13.

15. Liu X. (2012) Research on the implementation of value-added tax on traffic and transportation industry, Beijing Jiaotong University, Beijing

16. Liu X.K. (2004) Empirical study of skilled cooperation's impact on firms' bargaining pow, Chongqing University, Chongqing.

17. Qian C.H. (2013) "Construction industry 'Business Tax Reformed to VAT' project cost countermeasures and impact analysis", Construction Economy, no.7, pp. 18-21.

18. Tang H.B. (2016) "Business Tax Reformed to" VAT' impact on construction firms and countermeasures", Management Manager, no.1, pp. 41.

19. Tian Z.W. \& Hu Y.J. (2014) "Research on the difference of 'Business Tax Reformed to VAT' effect on Shanghai and the whole country", Journal of Shanghai University of Finance and Economics, no.2, pp. 75-82.

20. Tian Z.W. \& Hu Y.J. (2013) "Dynamic analysis of 'Business Tax Reformed to VAT' effect on tax burden of different industries", Finance and Economics, no.4, pp. 29-34.

21. Wang J.J. (2011) Research on the implementation of value-added tax on Construction industry, Northeast University of Finance and Economics, Jilin.

22. Wang J.N. (2014) Empirical study on 'Business Tax Reformed to $V A T$ ' impact on listed companies in logistics industry, Northeast Petroleum University, Liaoning.

23. Wang J.R. (2013) Research on 'Business Tax Reformed to VAT' reform on modern service industry, Shandong University of Finance and Economics, Shandong.

24. Yang M. (2014) Empirical study on 'Business Tax Reformed to VAT' impact on financial performance of listed companies, South China University of Technology, Guangzhou.

25. Zhang Y.H. (2008) "Foreign value-added tax system comparison and recommendations to our country". Modern Commerce Industry, no.3, pp. 46-47.

26. Zhang X. (2013) "China's export firms bargaining power measurement - based on China's industrial exports of bilateral 
arbitrary boundary analysis", Journal of Zhongnan University of Economics and Law, no.3, pp. 51-58.

27. Zheng D.P. \& Zhang D. (2016) "Supplier and customer participation in the impact of technological innovation performance - consider the bargaining power of suppliers and customers", Technology economy, no.6.

28. Zhao F. (2012) "The necessity of 'Business Tax Reformed to VAT", Business Economy, no.6, pp. 94-95. 